Tejavathi et al. /Journal of Tropical Forestry and Environment Vol. 9, No. 02 (2019) 101-107

\title{
Studies on the Factors that Restrict Sexual Reproduction and Fruit Setting in Memecylon flavescens: An Endangered Taxon
}

\author{
D.H. Tejavathi ${ }^{1 *}$, B.S. Sumalatha ${ }^{1}$, R. Nijagunaiah ${ }^{1}$, P. Anitha ${ }^{2}$, K. Gayatramma ${ }^{3}$ \\ ${ }^{1}$ Department of Botany, Bangalore University, Bangalore, India. \\ ${ }^{2}$ Department of Botany, BMS College for Women, Basavanagudi, Bangalore, India. \\ ${ }^{3}$ Department of Botany, MES College, Malleswaram, Bangalore, India
}

Date Received: 26-04-2019

Date Accepted: 20-12-2019

\begin{abstract}
Memecylon flavescens Gamble is an endangered taxon of Nilgiri region of Western Ghats. Extensive survey in the study area- Avalanche, Ooty made during 2015-18 has revealed a few interesting aspects about the sexual reproductive cycle. Fruit setting is substantially very low though profuse flowering occurs. Flowers are hermaphrodite, actinomorphic, tetramerous, pin type and protogynous, favouring crosspollination. Pollen fertility as assessed by Alexander's differential staining is about $30 \%$. Sections of flower buds have revealed the infestation by undescribed gallmidge (Diptera: Cecidomyiidae). In 90\% of the flower buds observed, gall midge galleries are seen at various levels in the flower bud, destroying the reproductive organs by larval feeding. Hence, negligible fruit setting is mainly due to gallmidge infestation. Protogynous nature and low percent of pollen fertility are added factors aggravating the effect on fruit setting.
\end{abstract}

Keywords: Memecylon flavescens, endangered, protogynous flower, gall midge infestation

\section{Introduction}

The genus Memecylon L. belongs to the family Melastomataceae includes more than 300 species distributed mainly in the old world tropics (Renner et al., 2007). In India, it is represented by 34 species, of which 18 species are endemic to Western Ghats and four species are endangered (Gamble 1919, Sivu et al., 2014). Memecylon flavescens Gamble, is endemic to Western Ghats and categorised under 'Endangered' with IUCN Id-31203. Gamble for the first time described this taxon based on his own collections from Sispara in 1884 (2133 MSL), Avalanche (2186 MSL) and Kundah in 1885 (2133 MSL). Murugan et al., in 2002 have reported the species from Kothayar and Mahendragiri. Sispara is at present identified under Mukruthi National Park, while Kothayar and Mahendragiri forest ranges are come under Kanyakumari Wildlife Sanctuary and Nelli Wildlife Sanctuary respectively. Avalanche has been recognised as reserve forest area, while Kundah is completely transformed into tea plantations. Since, entry into Sispara, Kothayar and Mahendragiri is restricted, Avalanche was selected as our study area.

Though Avalanche is categorised under reserve forest area, habitat destruction is continuously happening by various anthropological interferences. Introduction of wattles in the early part of $20^{\text {th }}$ century is another major threat to the survival of natural flora (Seshana, 2003). A patch of 40 individuals of M.flavescens was located, identified, and recorded through extensive survey of the permitted study area (Fig.1A). Frequent visits to the study area for three consecutive years from 2015-2018 has revealed a few significant aspects on flowering and fruiting behaviour. Though profuse flowering occurs during November to February, fruit setting is negligible. Withering of ovaries was noticed before the setting of fruit.

*Correspondence: tejavathi_hanu@yahoo.com

Tel: +919448924734

ISSN 2235-9370 Print/ISSN 2235-9362 Online (C) University of Sri Jayewardenepura 
We could collect only 21 fruits during the tenure of three years of study period. Hence, the present investigation is an attempt to identify the factors responsible for very low percent of fruit setting by analysing flower morphology, pollen fertility in addition to histological studies of flower buds of various stages.

\section{Material and Methods}

\subsection{Histology-flower buds}

Flowers/flower buds of various stages were fixed in FAA (Formalin: Acetic acid: Ethyl alcohol) for $48 \mathrm{~h}$ and transferred to $70 \%$ alcohol for preservation. Customary paraffin technique was followed. Microtome sections were taken at 12-15 $\mu \mathrm{m}$ thick and stained with Haidenhain's haematoxylin and counter stained with Orange-G. Photomicrographs were taken with cannon camera using Leitze binocular inverted microscope.

\subsection{Alexander differential staining to assess pollen fertility (Alexander, 1980)}

Alexander differential stain was prepared by mixing the following:

1. Ethanol (96\%)-20 ml

2. Distilled water-50 ml

3. Glycerol-40 ml

4. Acid Fuchsin-100 mg

5. Phenol-5 g

6. Lactic acid-2 ml

Pollen is dusted on to 1-2 drops of stain on slides and warmed lightly before placing the cover slip. The cover slip was sealed with fixogum to prevent evaporation. Slides were examined after 15-30 minutes. Incubation at $50^{\circ} \mathrm{C}$ for $2-4 \mathrm{~h}$, makes the stain deepens.

2.3 Modified cellophane method using PEG 10,000 in Brewbaker and Kwack's medium for in vitro pollen germination (Shashikumar, 2005)

Non-water proof cellophane strips measuring about $2.0-2.5 \mathrm{~cm}^{2}$ having a thickness of $0.01 \mathrm{~mm}$ were soaked in nutrient medium containing sucrose (10\%), Polyethylene glycol (10\%), Boric acid (100 ppm), calcium nitrate $(300 \mathrm{ppm})$ potassium nitrate $(100 \mathrm{ppm})$ and magnesium sulphate $(200 \mathrm{ppm})$ for $10-15 \mathrm{~min}$. Soaked each cellophane strip was placed on one side of a clean micro slide. Excess medium was drained off, using blotting paper. The slide with cellophane soaked in the germination medium was dried at room temperature. Pollen were dusted uniformly on the cellophane and enclosed in a Petri plates having filter paper lining on both the plates. The filter paper was moistened with distilled water to provide a $100 \%$ humid environment. The Petri plates were incubated in the dark at $26 \pm 2^{\circ} \mathrm{C}$ for varied periods. After incubation, the cellophane strip with pollen was stained with a drop of Alexander's stain. A cover slip, slightly bigger than the cellophane strip was placed on the slide and sealed with fixogum. The slide was observed under binocular Leitz microscope to record the percent and to measure the pollen tube length by ocular micrometer.

\section{Results and Discussion}

Perusal of literature and consultation of various herbaria (CAL, CALI, DD, FRC, KFRI, MH, PCM, TBGT) revealed that the species is known by only seven collections viz., Gamble 14,268 and Sivu 65,126 from Sispara, Gamble 16,161 and 16,168 from Avalanche; Gamble 20581 and Mathew PM 34,073 from western slope of Nilgiri ranges, adjoining Nilambur forests from Kundah and Murugan XCH 12,630 from upper Kothayar and Mahendragiri forest range. Gamble collections are represented in K, while others are in TBGRI, except Murugan XCH 12,630 which is deposited in St. Xavier College, Tirunelveli. Duplicate of the former three collections of Gamble are in CAL and that of the last one is in $\mathrm{MH}$. Based on the status of preservation and hand drawings of Gamble on the herbarium, Das et al., 2013 have considered the 
Tejavathi et al. /Journal of Tropical Forestry and Environment Vol. 9, No. 02 (2019) 101-107

Gamble 14,268 herbarium as lectotype. After Gamble, no other collector has reported this taxon from Avalanche, until we rediscovered in 2013 from the type locality.

\subsection{Flower morphology, percent pollen viability and germination}

Flowering was observed in only one plant among 20 of almost same age during our first visit to the study area, 10 plants in the second year, and 6 plants in third year. Variation in the number of plants that flower in each year indicate the inconsistency in flowering behaviour prevailing in this taxon.
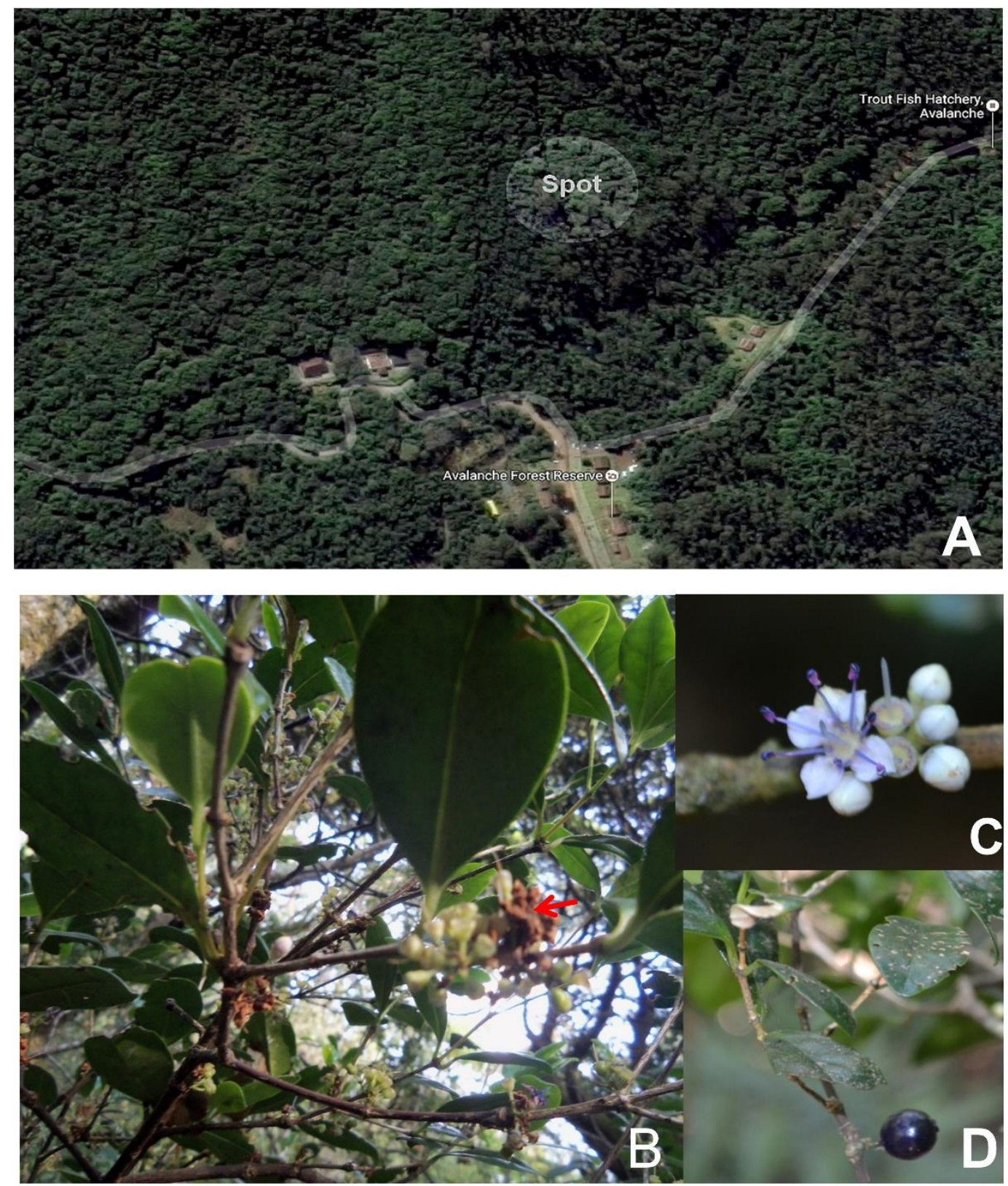

Figure 1. Memecylon flavescens; A-Google satellite image of the location; B-twigs of the plants showing normal flower with insect infested flowersarrow marked; C and D-A twig with a flower and mature fruit. 
Flowers are hermaphrodite, actinomorphic, pin type, protogynous, blue in colour, in axillary clusters, shortly pedicellate; calyx 4, companualte, obscurely lobed; petals 4, ovate-orbicular; stamens 8, epipetalous, filaments 2.5-3.0 mm long; ovary syncarpous, 7-8 carpels, single locule, 7-8 ovules, axile placentation; berry globose, violet blackish in colour (Figure 1B-D).
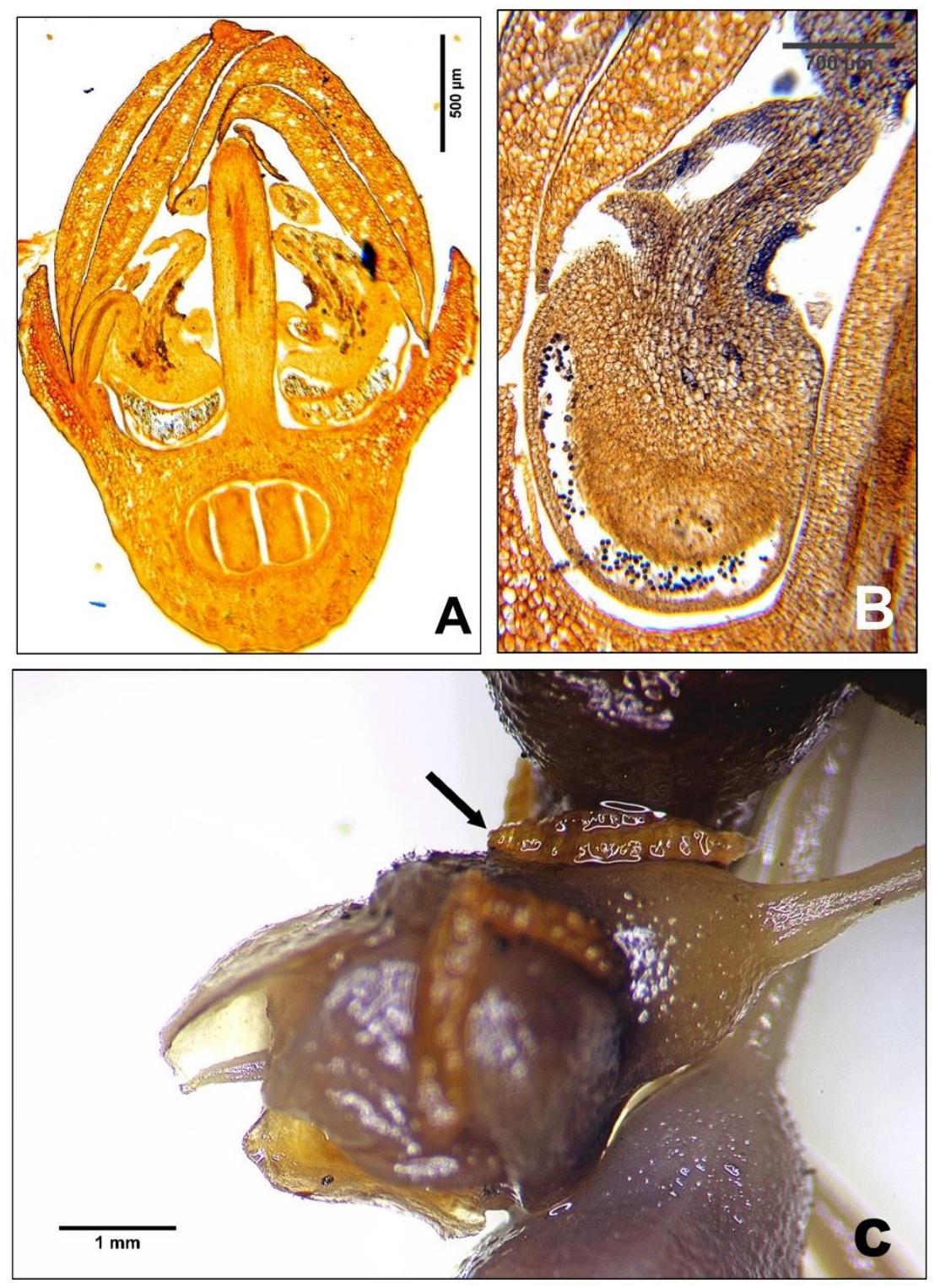

Figure 2. Flower morphology; A-Section of a flower showing protogynous nature; B-Section of a flower showing gland on horn shape appendage of the connective; C-Larvae on flower bud.

The protogynous and pin type flower usually favours cross-pollination as pistil maturity occurs before anthesis and stigma loses its receptivity prior to anther dehiscence (Figure 2A). The filaments are shorter than style and are folded over in such a way that the microsporangia are facing downwards and far away from stigma. The connective of the anthers is prolonged at the back to form a characteristic horn shaped appendage as reported in Memecylon heyneanum (Subramanyam, 1949). Each appendage has a gland facing the style in bud. Glands are concave in shape and its outermost layer consists of narrow elongated palisade-shaped cells with conspicuous nuclei and dense cytoplasm (Figure 2B). This looks like the secretary layer of the gland followed by two to three layers of compactly arranged parenchymatous cells. Morley (1976) has considered these distinctive connective glands as one of the characteristic features of the members of Memecyleae. Earlier studies have described these glands as nectary (Burck, 1891, 
Subramanayam, 1949, Venkatesh 1955). However, Buchmann and Buchmann (1981) have characterised the secretion from the connective glands of Mouriri myrtilloides and concluded that it is an elaiophore secreting oil rather than nectar as once believed. Vogel $(1969,1971)$ was the first to describe the presence of oil glands in the flowers of some families; Melastomataceae is one among them. The stamen elaeiophore of this nature are unknown in any other taxon of oil producing flowers (Buchmann and Buchmann, 1981). The glycerides secreted through this elaeiophore can be considered as floral rewards in addition to nectar and pollen.

The pollen grains were stained with Alexander differential stain (1980) to assess the percent of fertile pollen. Aborted pollen are more in number, about $40 \%$, which look green in colour, pale reddish coloured pollen with scanty cytoplasm were also observed amounting to $30 \%$, the remaining $30 \%$ of pollen which are fertile are bright red in colour. Initiation of pollen tube was recorded after 3-31/2 $\mathrm{h}$ of incubation. Maximum pollen tube length of $185 \mu \mathrm{m}$ was recorded after $5 \mathrm{~h}$ of incubation. Low percent of pollen viability was recorded in several other members of Melastomataceae. Low pollen fertility in sexually reproducing forms may be partly caused by environmental factors as was observed in Miconia pepericarpa, which has shown 42.4\% fertility in one year and 88.8\% in the following year (Goldenberg and Shepherd, 1998). Subramanyam (1942) has observed sterile pollen grains with various stages of degeneration in Leandra cordifolia, a member of Melastomataceae. In Miconia species (Melastomataceae), partial and complete male sterility due to the formation of large number of abnormal pollen grains is considered to be related to apomixis (Goldenberg and Shepard, 1998; Cortez et al., 2012). Abnormal pollen grains leading to pollen sterility is a common factor that was reported in all the apomictic species of Melastomataceae (Cortez et al., 2012).

\subsection{Histology}

Visual observations of flowers revealed two types; greenish violet and brownish-white coloured buds (Figure 1B). These buds were processed for microtomy. Observations of double stained sections have shown the occurrence of undescribed gall midge (Diptera: Cecidomyiidae) infestation. Brownish-white coloured buds are heavily infested, while greenish-violet buds which look healthy, are at initial stages. Thus, about $90 \%$ of the flower buds studied were infested with gall midge and the larvae have damaged the reproductive parts of the flower bud by vigorous feeding and formation of gallaries (Figure 2C). Large number of eggs and larvae with gallaries have observed at different levels in the flower bud (Figure 3A-F). In some flower buds, microsporangia are infected and in others, ovaries. An extreme condition was seen in some flower buds, that containing only larvae and gallaries enclosed by petals. Malformed anthers were also noticed in some flower buds because of gall midge infestation (Figure 3B-D). Kolesik et al., 2018 have observed gall midge infestation of flower buds in Alstoemeria that has led to the malformed flowers; turned necrotic later. Nearly $80 \%$ of the flower buds were infested in these ornamentals plants. Not all the gall midges are pests. A few beneficial species of gall midge prey on aphids, mites, scale insects, and bark beetle larvae thereby protecting the plants from other pests. Flower bud, fruit, and seedling feeding Cecidomyiidae are considered as potential biological control agents to reduce the rate of spread of invasive weeds (Adair et al., 2000). 


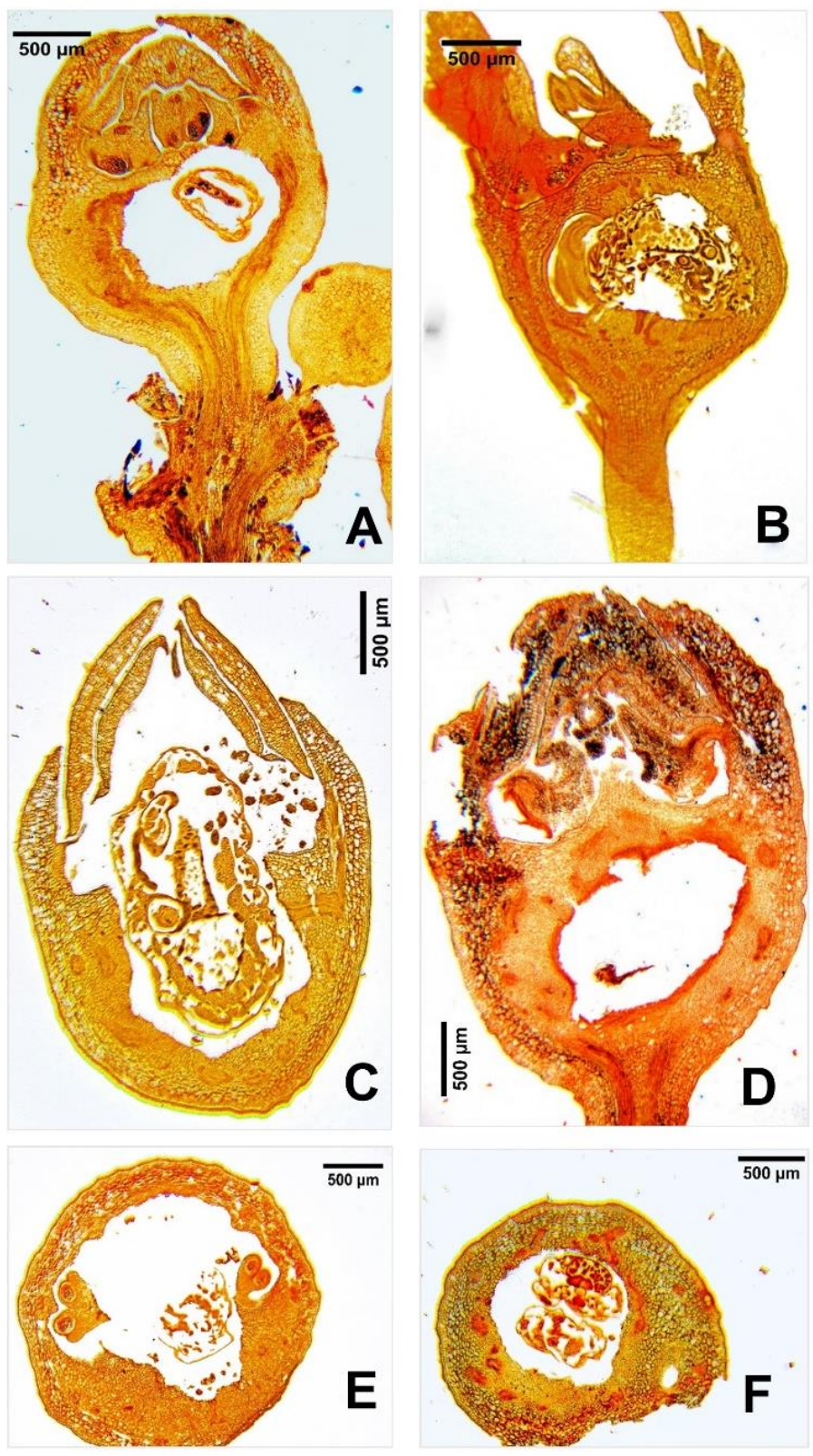

Figure 3. Section of flower buds showing insect infestation and galleries at various levels.

\section{Conclusion}

Protogynous nature of the flower, low percent of pollen fertility and severe gall midge infestation are the main factors leading to substantial reduction in fruit production. Habitat loss due to various anthropological interferences and introduction of wattles in the early part of the $20^{\text {th }}$ century in Avalanche, study area could be additional factors result in the restriction of propagation/ multiplication through sexual mode of reproduction.

\section{Acknowledgment}

Authors are grateful to Ministry of Environment, Forestry and Climate Change, New Delhi for funding this work. Especial thanks to Dr. S.Shashikumar, AGM, AVT Natural Products Ltd., Bangalore, for his help rendered at various stages. 


\section{References}

Alexander, M.P., 1980. A versatile stain for pollen fungi, Yeast and Bacteria. Stain Technology, 55:13-18.

Adair, R.J., Neser, S. and Kdesik, P., 2000. Australian seed-preventing gall midges (Diptera: Cecidomyiidae) as potential biological control agents for invasive Acacia spp. in South Africa, Proceedings of the $\mathrm{X}$ international symposium on Biological Control of Weeds, Montana state university, Bozeman, Montana, USA, pp 605-613.

Burck, W., 1891. Beitrage zur kenntnis der myrmekophilenp flanzen und der Bedeutung der extranuptialen Nectarine. Annales du Jardin Botanique de Buitenzong, 10:75-144.

Buchmann, S.L. and Buchmann, M.D., 1981. Anthecology of Mouriri myrtilloides (Melastomataceae: Memecyleae), an oil flower in Panama. Biotropia, 13:7-14.

Cortez, P.A., Carmello-Guerreiro, S.M. and Teixeira, S.P., 2012. Understanding male sterility in Miconia species (Melastomataceae) a morphological approach. Australian Journal of Botany, 60:506-516.

Das, M.D., Maity, D. and Parmanik, A., 2013. Lectotypification of Memecylon flavescens Gamble (Memecylaceae DC). Taiwania, 58:217-220.

Gamble, J.S., 1919. Flora of the presidency of Madras. Vol. 1. Third edition. Adlard and Son, Ltd. London, pp 503.

Goldenberg, R. and Shepherd, G.J., 1998. Studies on the reproductive biology of Melstomataceae in "Cerrado" vegetation. Plant Systematics and Evolution, 211:13-29.

Kolesik, P., Baker, G., Hill, K., Manners, A.G. and Dijkstra, E., 2018. New species of gall midge (Diptera: Cecidomyiidae) damaging flower buds of ornamental Alstroemeria plants. Austral Entomology, 57:285-291.

Murugan, C., Manickam, V.S., Josephine, M.M. and Sundaresan, V., 2002. Extended distribution of two rare and endangered taxa from Tirunelveli Hills, Western Ghats, Tamil nadu. Journal of Bombay Natural Historical Society, 99:545-546.

Morley, T., 1976. Memecyleae (Melastomataceae). Flora Neotropica, Monograph, 15:1-295.

Mathew, P. and Sivarajan, V.V., 1996. Flora of Nilambur. Bishen Singh Mahendra Pal Singh, Dehra Dun, pp 270.

Renner, S.S., Triebel, D., Almeda, F., Stone, D., Ulloa, C., Michaelangeli, F.A.R., Goldenberg, R. and Mendoza H., (Eds.) 2007 onwards. MEL names: a database with names of Melastomataceae, http://www.melastomataceae.net/MELnames/.accessed 25 April 2013.

Seshana, S. and Sandilya, T., 2003. Survey, Rapid Assessment and Restoration of vegetation diversity within Mukurthi National Park, Report, Gurukula Botanical Sanctuary, Kerala.

Shashikumar, S., 2005. Studies on pollen biology of a few horticultural important plants. Thesis, Bangalore University, Bangalore, India.

Sivu, A.R., Ratheeshnarayana, M.K., Pradeep, N.S., Santhoshkumar, E.S. and Pandurangan, A.G., 2014. A new species of Memecylon (Melastomataceae) from the western ghats, India. Phytotaxa, 162:4450 .

Subramanyam, K., 1942. Gametogenesis and Embryogeny in a few members of the Melastomaceae. Journal of the Indian Botanical Society, 21:69-85.

Subramanyam, K., 1949. On the nectary in the stamens of Memecylon heyneanum Benth. Current Science, 18:415-416.

Venkatesh, E.S., 1955. The structure and dehiscence of the anther in Memecylon and Mouriri. Phytomorphology, 5:435-440.

Vogel, S., 1969. Flowers offering fatty oil instead of nectar. Abstracts, XI. International Botanical Congress, Seattle, USA. pp 229.

Vogel, S., 1971. Olpruduzierende blumen, die durch olsammelnde bienen bestaubr werden. Naturwissenschafren, 58:58. 